\title{
JOURNAL.RU
}

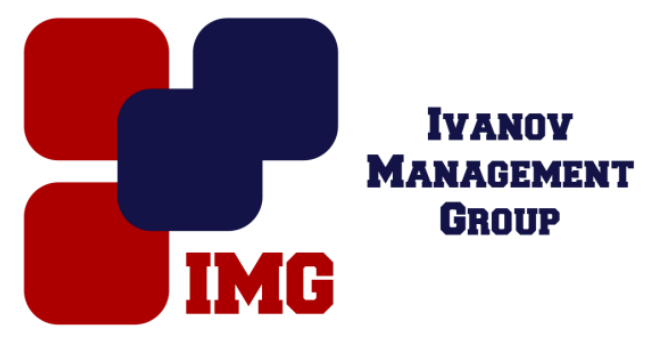

Салдаева Е.Ю., ГабитоваА.А. Поволжский Государственный Технологический Университет Йошкар-Ола, Россия

doi: $10.18411 / \mathrm{jj}-31-05-2017-66$

idsp 000001:1j-31-05-2017-66

\section{Заинтересованные стороны в системе менеджмента качества ФГБОУ ВО «ПТУУ}

\section{Аннотация}

В статье показан пример деятельности ФГБОУ ВО «Поволжский Государственный Технологический Университет» в работе с выявлением категорий заинтересованных сторон и определением их потенциальных потребностей в образовательной деятельности, что служит неотъемлемой частью проекта перехода системы менеджмента качества ФГБОУ ВО «ПГТУ»на новую версию стандарта ГОСТ Р ИСО 9001-2015 «Система менеджмента качества. Требования».

Ключевые слова: ГОСТ Р ИСО, заинтересованные стороны, удовлетворенность, социологическое исследование

Успешность любой организации зависит от удовлетворенности потребителей. Эта важная особенность нашла отражение и в новой версии стандарта ГОСТ Р ИСО 9001-2015.

В Поволжском Государственном Технологическом Университете (ПГТУ) с 2008 года успешно функционирует сертифицированная система менеджмента качества. В настоящее время ведется работа по реализации новых требований стандарта ГОСТ Р ИСО 9001-2015 г., который предусматривает выявление всех заинтересованных сторон (п. 4.2 ГОСТ Р ИСО 9001-2015).

Основной задачей ПГТУ является наиболее полное удовлетворение потребностей и ожиданий заинтересованных сторон, поскольку это оказывает решающее воздействие на достижение его главных целей. Университет 
постоянно взаимодействует с заинтересованными сторонами и в силу этого формирует механизмы определения их потребностей, ожиданий и влияния на его деятельность.

ПГТУ выделяет следующие категории заинтересованных сторон (Таблица $1)$.

Основная ответственность за определение и анализ потребностей и ожиданий заинтересованных сторон в университете возложена на институты, факультеты, кафедры и др. структурные подразделения. Для определения и анализа потребностей и ожиданий заинтересованных сторон данные ониреализуют следующие мероприятия:

- анализ вторичной информации, позволяющей получить представления о потребностях и ожиданиях заинтересованных сторон (заявки работодателей, заключенные договоры с организациями, сведения службы занятости, статистические данные, данные о конкурсе на направления и специальности, результаты исследований, проводимых другими вузами и пр.);

- социологические исследования абитуриентов, обучающихся, выпускников, сотрудников, работодателей в форме анкетного опроса;

- оценка конкурентной позиции университета на рынке образовательных услуг.

Университет определил и реализует систему мероприятий по обеспечению постоянных связей с потребителями и заинтересованными сторонами. Обеспечение связи ведется по двум направлениям:

- информирование о деятельности университета и её услугах (деятельность осуществляется в рамках процессов: «Формирование информационной политики», «Стратегическое планирование и управление университетом. Анализ данных работы вуза со стороны руководства для улучшения функционирования процессов жизненного цикла», «Подготовка к поступлению в вуз», «Прием в студенты», «Реализация образовательного процесса», «Дополнительное профессиональное образование», «Мониторинг и контроль») может совсем перечисление процессов убрать;

- обеспечение обратной связи с потребителями и заинтересованными сторонами (деятельность осуществляется в рамках процессов: «Мониторинг, анализ и улучшение»; «Взаимодействие с 


\section{потребителями», «Научные исследования и разработки», «Реализация образовательных программ»). \\ Университет ежегодно проводит SWOT-анализ с целью пересмотра заинтересованных сторон и их требований.}

Таблица 1.

Заинтересованные стороны и определены их требования

\begin{tabular}{|c|c|}
\hline Заинтересованная сторона & Потребность \\
\hline 1.Учредитель & $\begin{array}{c}\text { Устойчивая работа и развитие вуза; } \\
\text { Своевременные выплаты }\end{array}$ \\
\hline 2. Финансовые институты & $\begin{array}{l}\text { Нестабильность университета; } \\
\text { Высокие цены на обучение; } \\
\text { Утечка персонала } \\
\end{array}$ \\
\hline $\begin{array}{c}\text { 3.Потребители образовательных } \\
\text { услуг }\end{array}$ & $\begin{array}{c}\text { Получении актуальных, практических знаний, востребованных на } \\
\text { рынке труда; } \\
\text { Очники хотят «интересно жить и проводить время в стенах } \\
\text { института»; } \\
\text { Заочники иметь гибкий график учебного процесса } \\
\end{array}$ \\
\hline 4. Местное сообщество & $\begin{array}{l}\text { Трудоустройство; } \\
\text { Обучение }\end{array}$ \\
\hline $\begin{array}{l}\text { 5. НКО и общественные } \\
\text { организации }\end{array}$ & $\begin{array}{c}\text { Выполнение учебного процесса; } \\
\text { Прибавление количество научных трудов; } \\
\text { Увеличение преподавателей с учеными степенями } \\
\end{array}$ \\
\hline 6. Среда массовой информации & $\begin{array}{l}\text { Коммуникативная деятельность в вузе; } \\
\text { Распространение газет, журналов; } \\
\text { Распространение инноваций }\end{array}$ \\
\hline 7. Органы власти & $\begin{array}{l}\text { Заинтересована чтобы институт, используя свои ресурсы, } \\
\text { организовывал и участвовал в городских мероприятиях; } \\
\text { Подготовка востребованных технических специалистов }\end{array}$ \\
\hline $\begin{array}{l}\text { 8. Инвесторы, спонсоры, } \\
\text { организации-работодатели }\end{array}$ & $\begin{array}{c}\text { Устойчивая работа и развитие вуза; } \\
\text { Постоянное увеличение количество студентов; }\end{array}$ \\
\hline 9. Поставщики & $\begin{array}{c}\text { Организация на их базе различных мероприятий для школьников; } \\
\text { Профориентационные мероприятия; } \\
\text { Предоставление скидок обучающимся рабочим }\end{array}$ \\
\hline 10. Подрядчики и субподрядчики & $\begin{array}{l}\text { Своевременные выплаты; } \\
\text { Выполнение соглашения }\end{array}$ \\
\hline $\begin{array}{l}\text { 11. Органы надзора и контроля в } \\
\text { сфере образования }\end{array}$ & $\begin{array}{c}\text { Выполнение законодательных требований; } \\
\text { Наличие компетентного персонала }\end{array}$ \\
\hline 12. Работники & $\begin{array}{c}\text { Возможности для карьерного и/или профессионального развития; } \\
\text { Достойное материальное вознаграждение и его своевременная } \\
\text { выплата; } \\
\text { Предоставление нематериальных льгот; Социальные гарантий; } \\
\text { «уверенности в завтрашнем дне» }\end{array}$ \\
\hline 13. Отраслевые организации & $\begin{array}{c}\text { Чтобы сотрудник с минимальным отрывом от производства } \\
\text { получил актуальные знания, применимые в направляющей } \\
\text { организации; } \\
\text { Предоставление гибкого графика обучения, позволяющего } \\
\text { минимизировать отрыв сотрудника от рабочего процесса }\end{array}$ \\
\hline
\end{tabular}

Понимание основных требований выделенных заинтересованными сторонами дает нам возможность учитывать их при формировании и реализации стратегии. 
1. ГОСТ Р ИСО 9001-2015 Системы менеджмента качества. Требования.

2. ГОСТ Р 57189-2016/ ISO/TS 9002:2016 Системы менеджмента качества. Рекомендации по применению ИСО 9001

3. Системы менеджмента качества : учебно-методическое пособие к выполнению курсовой работы / Е. Ю. Салдаева - Йошкар-Ола : Поволжский государственный технологический университет, 2015.

4. Федюков, В. И. Аудит качества: учебное пособие/ В. И. Федюков, Е. Ю. Салдаева. Йошкар-Ола: Йошкар-Ола : Поволжский государственный технологический университет, 2014. -185 с. 